\title{
Abercrombie's green-wedge vision for London: the County of London Plan 1943 and the Greater London Plan 1944
}

\begin{abstract}
This paper analyses the role that the green wedges idea played in the main official reconstruction plans for London, namely the County of London Plan 1943 and the Greater London Plan 1944. Green wedges were theorised in the first decade of the twentieth century and discussed in multifaceted ways up to the end of the Second World War. Despite having been prominent in many plans for London, they have been largely overlooked in planning history. This paper argues that green wedges were instrumental in these plans to the formulation of a more modern, sociable, healthier and greener peacetime London.
\end{abstract}

Keywords: Green wedges, green belt, reconstruction, London, planning

\section{Introduction}

Green wedges have been theorised as an essential part of planning debates since the beginning of the twentieth century. Their prominent position in texts and plans rivalled that of the green belt, despite the comparatively disproportionate attention given to the latter by planning historians (see, for example, Purdom, 1945, 151; Freestone, 2003, 67-98; Ward, 2002, 172; Sutcliffe, 1981a; Amati and Yokohari, 1997, 311-37).

From the mid-nineteenth century, the provision of green spaces became a fundamental aspect of modern town planning (Dümpelmann, 2005, 75; Dal Co, 1980, 141-293). In this context, the green wedges idea emerged as a solution to the need to provide open spaces for growing urban areas, as well as to establish a direct 
connection to the countryside for inner city dwellers. Green wedges would also funnel fresh air, greenery and sunlight into the urban core. Their wedge form would allow them to expand at the periphery in relation to urban sprawl. The origins and development of this idea in Britain have been recently examined (Lemes de Oliveira, 2014); however, there is still no account of the role that green wedges played in proposals for the post-war reconstruction period. Many authors have examined the most well known reconstruction plans for the capital, such as the Royal Academy Plan, the MARS plan from 1942 (Marmaras and Sutcliffe, 1994, 431-53; Gold, 1995, 243-67) as well as Patrick Abercrombie's County of London Plan and Greater London Plan (see Larkham Adams, 2011, 2; Ashworth, 1954; Cherry, 1988; Cullingworth, 1975; Ward, 2004, 97-99; Bullock, 1994, 87-101). In spite of this large number of analyses the significance of green wedges has been notably understated.

This article thus aims to help fill this gap by discussing the significance of the concept for the main reconstruction plans for London envisaged during the Second World War. The study shows how green wedges were fundamentally used as symbols of the hope of a better future; as a strategy to improve public health by providing access to greenery, sunlight and fresh air; to secure a direct connection from the inner urban areas to the countryside; to increase the amount of recreational space; and as planning instruments used to create a new urban structure for London.

\section{Green wedges and London's regional planning}

Reactions to the consequences arising from uncontrolled growth were at the core of town planning ideas from the mid-nineteenth century. Problems with public health, overcrowding, congestion, transportation, poor housing conditions, pollution and 
deficiency in the amount and distribution of green spaces were paramount. At the turn of the century, London's six million inhabitants occupied not only the inner-city areas, but-facilitated by the electric tram and motor vehicles-also strips of land along arterial routes, suburbs and neighbouring rural areas (Sutcliffe, 1981b, 52). At the same time that this tentacular form of growth into the open country was seen as a threat by social actors such as rural preservationists (Cherry, 1975, 9-25), some professionals would call for a reciprocal extension of the countryside into towns. Patrick Geddes $(1915,96-7)$, for instance, argued that 'the children, the women, the workers of the town can come but rarely to the country. As hygienists, and utilitarians, we must therefore bring the country to them' and that towns, 'once in true development, they will repeat the star-like opening of the flower with green leaves set in alternation with its golden rays'.

Green wedges emerged in relation to the prominence of radial growth. They derived from the radial parks and parkways of early park system plans for American cities such as Buffalo and Boston, however would acquire a specific identity with Rudolf Eberstadt, Richard Petersen and Bruno Möhring's runner-up entry to the 1910 Greater Berlin Competition. Presented by Eberstadt (1911) at the 1910 RIBA Town Planning Conference, green wedges were seen as the most appropriate provision of open spaces for modern towns. The circulation of ideas during the formative years of modern town planning was intense and, after the event, the concept immediately permeated planning discourses in Britain. It was mostly advocated by professionals involved with the Liverpool School of Architecture's Department of Civic Design, such as Henry Vaughan Lanchester, Patrick Abercrombie and Thomas Mawson. The concept - as it appeared in British planning debates - was in opposition to that of the 
green belt, which was criticised for not addressing the need for urban green spaces and for immobilizing the urban structure.

The history of green wedges in Britain in the period goes alongside the development of regionalism. Regional planning had already been promoted at the RIBA Conference by G. L. Pepler and A. Crow. In the article 'Town Planning in Greater London: the need for co-operation', from 1912, Abercrombie called for coordination among the local authorities for a conjoined effort to plan London and its surrounding areas and for the implementation of wedges of greenery. Similarly to what had been suggested by Geddes and Eberstadt, Abercrombie stated that the nature of the ribbon development inherent to many contemporary towns in Britain had generated wedge-like gaps that_instead of being seen as negative space-should be conceptualised as positive green spaces reaching far into the urban fabric. They presented valuable opportunities not to be missed. Hampstead Garden Suburb, Hampstead Heath, Parliament Hill and Regents Park would be just one of many wedges that could be created in the capital. Since then, the green wedges idea became almost a constant in Abercrombie's work. The idea would reappear in several other of his works, such as in the plans for Dublin, Sheffield, Plymouth and Hull, among others.

The London Society Development plan, published in 1918, was another step towards regional planning and the promotion of greenery. The plan highlighted two green wedges, one in the Epping Forest and another one in north-west London, from Stanmore to the Brent Reservoir (Lemes de Oliveira, 2013).

The inter-war period saw regional planning flourish in Britain, influenced mainly by the works of Geddes, Pepler, Crow, Unwin and Abercrombie (Hewitt, 2011, 560). Also during this period, green wedges were used in plans in numerous countries 
across the world, such as Australia, Germany, Cuba and Brazil. In Britain, the idea gained momentum with the publication of 'Open Spaces' by Pepler (1923), in which a diagram including four green wedges and a circular parkway linking them up formed a model for park system plans. They would be essential in the promotion of healthy environments by enlarging the amount of open space inside cities and funnelling in fresh air from the countryside. In both reports of the Greater London Regional Planning Committee (GLRPC), from 1929 and 1933, green wedges were incorporated into the plans, linking the green belt to London's core. Abercrombie in his book Town and Country republished Pepler's diagram as a model for park system plans (1933, 147). By that time, the initial theoretical opposition between belt and wedges in Britain had been resolved and they were promoted, in many cases, as complementary elements of citywide or regional park systems. These plans and texts announced the further use that green wedges would have in plans made during and after the war in the country.

\section{The context of post-war reconstruction}

While the inter-war period had seen the growth of regional plans and claims for the preservation of the countryside (Sheail, 1981); reconstruction of war-damaged towns, construction of new settlements and the move towards the coordination of town and country planning became priorities in the post-war period (Hall and Tewdwr-Jones, 2011, 55-79).

Lord Reith, the Minister of Works and Planning between 1940 and 1942, was given the responsibility to work on reconstruction policy to make viable the 
replanning of existing towns and cities. The most fundamental questions at issue were those related to the private ownership of land and to planning itself.

Regarding the first, professionals such as D.E. Gibson, City Architect of Coventry, would argue for 'some form of nationalisation of the land' as the 'only solution for Britain' $(1940,579)$ because, as fellow commentator A.W. Crampton asserted: 'the private ownership of land [was] the cause that fetters modern development' $(1941,4-$ 5). Another notable claim for such a move can be found in the argument of the Director of the Institute for Research in Agricultural Economics at Oxford University, C.S. Orwin, that "whatever way the problem is regarded, it seems impossible to be fair to the community so long as private property in land persists' and that 'acquisition of the freehold of the land by the State ... must be accepted as a prerequisite of planning control' (The Builder, 1942b, 333). In January 1941 Reith established the Expert Committee on Compensation and Betterment, the Uthwatt Committee, which although not as bold as some expected, formulated a legal framework to support the compulsory purchase of areas needed for reconstruction plans.

Secondly, the question of planning involved the move towards the decentralisation of population and industry away from congested areas, the coordination between town and country planning, and the establishment of visionary plans. In this context, the Barlow Report, published in 1940 by the Royal Commission on the Distribution of Industrial Population, outlined the principles of the reduction of population from congested areas and the decentralisation of industry. It presented an opportunity to promote national planning and to consider more efficiently how to control land use (Moore, 2012, 3). Soon Reith created the Consultative Panel on Physical Reconstruction, a panel of twenty-one expert advisers, which included names such as 
Abercrombie, Barlow, Osborn and Stamp (Bullock, 2002, 14 and NA HLG 86/7, 1941-2). In 1942, the Report of the Committee of Land Utilisation in Rural Areas, known as the Scott Report (Ministry of Works and Planning, 1942), defended a better coordination of town and country planning and stressed the need to preserve agricultural land.

The most intensive period of bombing in Britain occurred between September 1940 and May 1941. The destruction of housing was most noticeable, but losses covered a wide range of building types (Flinn, 2012, 226). The end of the Blitz opened up a scenario of hope and enthusiasm, in which planning for the future became an exciting opportunity (Ashworth, 1954, 227; Tiratsoo, 2000, 34; Hasegawa, 1999, 138; Bullock, 2002, 5). This can be seen for instance in H. V. Lanchester's model for reconstruction to be applied to large cities, summarised in a diagram from the end of 1941 (see Figure 1). This is a development of his 1908 and 1910 diagrams and illustrated the city core, four green wedges and four built-up areas. Ralph Tubb's (1942) park system plan for London combining green wedges with a round six-mileradius parkway linking them up (see Figure 2), and the linear MARS plan of 1942, also featuring conspicuously wedge-like formations are further attempts to influence the future reconstruction of London.

INSERT FIG. 1 HERE (Lanchester)

INSERT FIG. 2 HERE (Ralph Tubbs)

In addition, green wedges were major features in a diagram by Arthur Trystan Edwards published in 1943 (see Figure 3). He had joined the department of Civic 
Design at Liverpool in 1911, worked for the Ministry of Health after the end of the First World War and founded the Hundred New Towns Association in 1933. The diagram proposed a radical reorganisation of London into a central area plus four axis of development, with four enormous green wedges between them. For Trystan Edwards, the wedge should be 'a new element in urban planning' and an 'alternative to the Green Belt'.

\section{INSERT FIG.3 HERE (Trystan Edwards)}

Moreover, replanning involved bombed as well as non-bombed areas that were perceived as in decay. As Larkham and Lilley (2001, 1-6) showed, replanning was not only undertaken by bombed towns, as those where little or no damage had occurred joined in the realisation of plans. In March 1941, the Ministry of Works asked the London County Council (LCC) and the City of London to draw up reconstruction plans (Marmaras and Sutcliffe, 1994, 434) 'without paying much attention to existing town planning law' (Carter and Goldfinger, 1945) as a new legal framework was being formulated. Still in 1941, Reith lectured in many bombed cities, such as Coventry, Southampton, Plymouth and Portsmouth, encouraging local governments to 'plan boldly' and 'comprehensively' (See Essex and Brayshay, 2008, 437-61; Hasegawa, 1992).

Indeed, it was with the focus on bold planning interventions brought up by the war and the promise of government support and a legal system to give planning effective transformative power that many plans for bombed cities would start, including those for London. The problems were many. The destruction caused by the air raids, 
congestion of traffic and people, uncontrolled mix of uses, poor housing conditions and shortage of open space were central.

\section{The County of London Plan 1943: 'From garden to park, from park to parkway, from parkway to green wedge and from green wedge to green belt'}

London's uncontrolled urban and population growth had been a cause for concern for over a century. At the city scale, this had led to inner-urban problems, such as overcrowding, lack of green spaces and their ill-distribution (see Figure 4), an obsolete road system, unsanitary conditions, inadequacy of housing supply, and a haphazard mixture of incompatible land uses (LMA LMA4062/06/040, 1943). At the regional scale, the absence of a plan had allowed ribbon development to stretch far out into the countryside, urbanising the neighbouring areas and suburbanising towns.

Only a month into the Blitz, the LCC was already discussing alternatives for the future of the capital. The minutes of a meeting held on 7 October 1940 evidenced the two main alternatives: rebuild London as it was - as had been done after the Great Fire of London of 1666-or 'redevelop the whole of London on an ideal scheme'. Lewis Silkin, who was then an MP and would later become Minister of Town and Country Planning, urged the council to be visionary, stating that 'London must not be rebuilt as it was before the war. We had (sic) a great opportunity and we must take it' (LMA CL/TP/1/33, 1940b, 2). Lord Latham (1942, 421-3), the Leader of the LCC, also corroborated the view that London should not incur the same 'mistake' twice: 'Wren's great plan for the City, after the Fire, was never put into execution. Clashes between irreconcilable interests supervened. Neither this nor any other condition must be allowed to prevent the carrying out of the twentieth-century plan of London'. The 
LCC Architect, F.R. Hiorns was also in favour of such a move, as there was a "case for comprehensive improvement on bold lines' (LMA CL/TP/1/33, 1940c). Despite these intentions, the problem of compensation and acquisition of land from private owners for 'the reconstruction of London on a vast scale' was paramount. In this light, it was considered how long it would take to acquire a freehold of all of London, if the council were given 'a free hand and a large staff' (LMA CL/TP/1/33, 1940b, 1). The first draft of the 'Memorandum on Replanning and Reconstruction of London' went further and stated that the war damage provided not only the opportunity, but also 'the excuse (if such [was] needed) for combining re-planning with reconstruction' (LMA CL/TP/1/33, 1940a). The acquisition of the whole of London was once again contemplated, as it would ultimately put the problems of separate ownerships of property to rest and facilitate the implementation of an ideal plan. Furthermore, the area to be acquired should not be limited to the county, but extend to the boundaries of Greater London.

At the end of 1940, although issues arising from a large-scale plan were brought up within the Council meetings, there was a feeling that 'financial difficulties must not stand in the way' of the creation of a new London (LMA CL/TP/1/33, 1940d, 2). The process was swiftly set in motion. In February 1941, the Architect of the Council suggested the appointment of Patrick Abercrombie as town planning consultant (LMA CL/TP/1/33, 1941a), in anticipation of the Council being asked by the Minister of Works and Buildings to prepare a plan, which happened the following month (LMA CL/TP/1/34, 1943a). Abercrombie's appointment was confirmed in a letter from 8 April to draw up the plan with the LCC architect J.H. Forshaw (LMA CL/TP/1/34, 1941). 
Abercrombie was professor of Town Planning at University College London and was the most prominent name in British planning at the time, having worked in many regional plans across the country. Granted Abercrombie's status -inasmuch as he was the main individual actor involved in the official plans for the capital and one of the most fervent supporters of the green wedges idea-analyses of his plans and indeed of his planning ideas miss a significant point if they do not consider his views on green wedges.

The County of London Plan aimed at reorganizing London into a series of selfsufficient communities, to separate conflicting land uses, update the housing stock, improve the traffic system and to "provide a properly coordinated system of parks throughout the whole County with continuous green wedges or parkways leading out to the Green Belt and linked at the centre by an inner "Green Ring" (LMA LMA4062/06/040, 1943).

Indeed, according to Abercrombie and Forshaw (1943, 42), the park system plan for the County was 'a practical application of the theory of the green wedges' (see Figure 5). They argued that 'the existing open spaces within the County and beyond [were] already loosely grouped in the form of wedges ... happily to be found between the radiating sprawl of outer London'. Accordingly, their development would be 'strategically disastrous', and as a result the plan proposed 'to base the park system' $(1943,38)$ on these wedges of open space.

INSERT FIG. 4 AND 5 HERE (Existing open spaces and proposed green spaces)

The perceived need for more green spaces and their coordination into a linked system was presented as a response to a number of considerations. Firstly, they would 
allow for a more spacious - and therefore healthier and more modern-environment. This would guarantee an adequate influx of fresh air and access to sunlight, and provide recreational spaces throughout the entire county. Secondly, and mostly through the use of green wedges, they would create a direct connection to the countryside. Thirdly, wedges of greenery would help form the proposed community boundaries and establish buffer zones along lines of traffic.

Having in mind that the tuberculosis death-rate and the infant mortality rate in London were $50 \%$ higher than, for instance, the average of the boroughs and urban districts in Hertfordshire (Reiss, 1943, 254), planning 'spaciously' - with generous provision of green spaces and their adequate distribution-was seen as key to achieving a healthy environment. At a lecture given at the Royal Sanitary Institute on 19 November 1943, Forshaw made it clear that the main aim of town planning was 'to secure the health and welfare of the people in their homes, at work and in their leisure' and that 'a more generous spacing of buildings, particularly flats, and a more open type of development for commercial buildings will allow the unpolluted air and sunlight to exert their beneficial effects' $(1943,14-5)$. In this light, the plan set out to provide four acres of open space per 1,000 inhabitants in the inner areas and three more in the outer zones, reaching a standard of seven acres. This would have at least doubled the amount of green spaces in the capital (LMA CL/TP/1/34, 1944, 4). Silkin $(1943,5)$ also made clear how the premise of the need to create more open spaces was at the forefront: 'the plan provides for a considerable addition of open space', which, combined with works in infrastructure, 'will result in less land remaining available for housing'; a significant amount of industry would also 'have to go too'. By the time of the plan's preparation, the publication of the Barlow Report signalled that the redistribution of population and industries away from London would be carried 
forward and that of the Uthwatt Report indicated that the matter of compensation would not necessarily be an impediment to executing the new plan. This meant, respectively, that London could be replanned much more 'spaciously' - as it would accommodate fewer people (LMA CL/TP/1/34, 1944, 4) - and that large-scale moves, which would be convenient, for instance, for the update of the traffic system and the creation of large green spaces, would not be an irresolvable matter due to litigation over compulsory purchase of land. This legal framework forged the initial conditions of existence for the application of the green wedges idea for London, although more powers would be necessary for their full realisation.

Many commentators have already pointed to the influence of the Barlow Report on Abercrombie's views regarding stopping sprawl by the means of a green belt (See, for example, Hall and Tewdwr-Jones, 2011, 64). However, it is to be reinforced that the plan was clear in stating what the limits of the green belt alone were, and that the focus should be on a conjoined approach: 'the Green Belt and surrounding countryside need bringing more into the centre through green wedges formed by the existing undeveloped public land' (Abercrombie and Forshaw, 1943, 38) while parkways along the ring roads would give access from one wedge to another. The park system was to be organised on different scales and create a framework starting from the smallest and most local open spaces to the forest reserves in the countryside. In essence, the plan's ambition was that the dweller could get from doorstep to open country through an easy flow of open space: 'from garden to park, from park to parkway, from parkway to green wedge and from green wedge to Green Belt' (Abercrombie and Forshaw, 1943, 39) (see Figure 6).

INSERT FIG. 6 HERE (Regional park system plan for the county) 
The plan described thirteen areas to be transformed into green wedges leading towards the green belt, including the axes St. James's Park-Greenford, Regent's Park-Hampstead Heath, Victoria Park-Lee Valley, Wanstead Flats-Epping Forest, a couple radiating out of Greenwich Park, Ruskin Park-Crystal Palace, and others (Abercrombie and Forshaw, 1943, 39-40). The green wedges are loosely represented in the drawings and require some imagination to be fully visualised; nonetheless, it is important to note how much emphasis was put on trying to make the idea work without a hyper-extensive programme of demolitions and making it the centrepiece of the park system plans.

The contemporary recurrent theme of linking green spaces with the traffic system (Lemes de Oliveira, 2014, 360-2) was adopted in the LCC Plan. For Forshaw (1943, 15), 'an essential protection the community needs is against the danger and noise of through traffic - a protection to be secured by a precinctal arrangement of roads or the presence of open spaces and green wedges as buffers between built-up areas'. Greenery would be buffer zones between the communities, encouraging their identity and breaking up the urban form. Most importantly, green wedges would help separate residential areas from the main lines of traffic, as well as from areas of unwanted proximity such as factories.

It was anticipated that allotments would become a 'war necessity' and that the demand would eventually decline with peace. The plan is rather dismissive of them, suggesting that they be dispersed within the residential areas, as their concentration had 'negligible, if any, amenity value' (Abercrombie and Forshaw, 1943, 39-40). 
If in 1940 there was an overall feeling of idealism in the political spheres as well as in the architects' visions, by 1943 the impasse was set between idealism and scepticism over the plan's feasibility and financial implications. On the one hand, it is significant to note that the idealism of the park system plan resonated positively with the local authorities and other bodies, who were requested to send their comments about the plan back to the LCC by the end of 1943 (LMA CL/TP/37, 1944; See also NA HLG 79/375, 1943-4; NA HLG 79/376, 1943-6). Important individual and social actors also supported the scheme (see, for instance, Lanchester, 1943, 41), or even encouraged a larger amount of green space. They included the Chief Officer of the Parks Department, who was delighted with the plan; the RIBA, which considered four acres reasonable provided that an additional three acres were added in the outer zone; the Minister of Town and Country Planning, who welcomed the proposal and suggested that the amount of green space should even be increased to more than four acres wherever possible; the Minister for Agriculture and Fisheries, asking for allotments to be considered in addition to the four-acre standard; or the TCPA, who thought that the four-acre standard was far too low (LMA CL/TP/1/34, 1943b, 3; see also Reiss, 1943, 254 and Cracknell, 1943, 118).

However, on the other side of the spectrum, there were those more directly involved with financial matters in the LCC who would cry for restraint. For instance, A.R. Wood, the Comptroller of the Council, in a report from 31 May 1943, argued that the realisation of the plan would be an 'impossible achievement' without much enlarged financial resources being made available. The Comptroller was concerned that much rateable value had been lost with the bombing and more still would be lost with the dedication of a much increased area to roads and open spaces. In addition, national economic support was elusive and viewed with suspicion. If the provision of 
four acres per 1,000 people were to be achieved, then one-fifth of the whole area of the county would be public open space and 'would involve capital expenditure nearly as large as the Council had spent on the whole of its housing operations during the fifty years up to 1939' (LMA CL/TP/1/34, 1943c, 2; see also LMA CL/TP/1/34, 1945). Herbert Westwood, the Valuer, was no less scandalised by the planned green space provision and urged the Council not to commit to 'carry out any of the proposals in the plan', as the cost was 'incalculable' (LMA CL/TP/1/37, 1943). Westwood went on to warn that even assuming that these proposals were only tentative and diagrammatic, 'the publication of the Plan may be a cause of embarrassment to the Council' (LMA CL/TP/1/34, 1943c, 3). Against this advice, the plan was indeed published in July 1943 and exhibited to the public for two months (LMA/4062/06/040, 1943).

In 1944, to break the deadlock, Forshaw suggested that an interim objective of a two-and-a-half acre standard would be a good compromise and highlighted that Abercrombie was in 'full agreement' with this (LMA CL/TP/1/37, 1944; for more on the controversies between the Valuer and Forshaw, see: Bullock, 1994, 5-7). This was accepted by the LCC Town Planning Committee as a phase towards the sevenacre 'target for ultimate achievement' (LMA CL/TP/1/37, 1945).

The green-wedge based park system in the County of London Plan acted as a precursor to the Greater London Plan 1944. The county plan set forward the principle of articulating a closely linked park system from neighbourhood to regional scale. It converted the wedge-like gaps between development along traffic lines and river valleys as the basis upon which to build a comprehensive system of greenery. The solution for the lack of green spaces was to increase the County's baseline ratio to seven acres per 1,000 inhabitants-which, as discussed above, was severely 
questioned-while dealing with their ill distribution involved the elaboration of a plan. Green wedges were the driving force behind the park system plan.

\section{The Greater London Plan 1944: green wedges and the quest for regional}

\section{planning}

The Greater London Plan was the chance to resolve the inter-war quest for regionalism. Soon after the LCC started working on its plan, discussions about the need to plan regionally started to emerge. In September 1941, in a meeting that included Abercrombie, Pepler and Forshaw, it was noted that the 'outside authorities were highly suspicious' of the LCC plan (NA HLG 71/116, 1941c). To avoid a multitude of local authorities' plans, it was agreed that 'the plan must be prepared by one mind giving whole time attention to it' and that the Ministry should ask Abercrombie to carry out a plan over the Greater London area on behalf of the Standing Conference on London Regional Planning (NA HLG 71/116, 1941a, 1; see also NA HLG 71/116, 1941b; The Builder, 1942a, 563). Upon the publication of the County of London Plan, Silkin $(1943,5)$ stated how difficult the task had been, as the authors suffered from the fact that they were restricted to making proposals only within the 'arbitrarily created' borders of the county, excluding also the jurisdiction of the City Corporation.

The general ideas of population relocation beyond the outer green belt, control of London's growth and the improvement of inner city standards were developed and embraced more fully in the Greater London Plan 1944. This plan assumed that Greater London's population would not increase above the 1938 figure of about ten million people and that decentralisation should occur by relocating a million people 
from the inner ring to expanded towns and eight new satellite towns, which were to be built 50 miles away from London's core.

Sprawl was to be controlled by creating a green belt on the 1939 urban fringe. Abercrombie proposed establishing four rings to structure the general master plan, the first encompassing the inner central area, the second circling London at around 12 miles from Charing Cross, the third being the 'Green Belt Ring', with a mix of playing fields and farms, and the fourth the 'Outer Country Ring'. In addition, the transformation of the existing city should happen mainly by improvements made to the traffic system, the formation of self-sufficient communities and the provision of a comprehensive park system.

The park system plan for Greater London was considerably more elaborate than that of the County plan. It prescribed a standard of ten acres per 1,000 people, as opposed to the seven-acre standard proposed by the County plan. The proposal for Greater London also presented a more developed description of the system's main ambitions, functions and components.

The overarching principles of using green spaces to provide salubrious spaces for recreation, to create continuous connections to the countryside and define selfsufficient communities were pursued. It must be remembered that one of Abercrombie's reoccurring core preoccupations regarding the provision of a park system for London's region was the lack of connectivity between the built-up centre and the verge of the urbanised area. Making use of Howard's term, he assumed that the country was the real 'magnet' attracting Londoners. This would generate a 'centrifugal urge to fly from bricks and mortar and get into the country' (Abercrombie, 1945, 97; NA HLC 85/17, 1944). The need for access to the countryside was a common preoccupation at the time, as can be seen in a report from 
14 January 1944 arguing that London's lack of green spaces had reached a point that required 'taking children out in buses to Outer London to see its green fields'. This would be a 'further indication of the necessity of keeping Outer London's open spaces free of building' (NA HLC 85/17, 1944, 2). Consequently, green wedges were at the core of the proposed park system as the most appropriate typology of green space to facilitate the achievement of such an objective. They were referred to as 'interpenetrating wedges of varied open land' (Abercrombie, 1945, 103). Any land leading from the heart of London to the open country that was considered to be essential for the creation of these green wedges should be bought on similar lines as suggested by the Uthwatt Report, be kept free from building and be open to the public.

The park system plan would consist of a range of typologies from the small scale of playgrounds and town squares to the large scale of green wedges and green belts. The idea of allowing residents to go from their house in the inner city to the open countryside through green spaces-formerly put forward in the County of London plan-was pursued. Abercrombie alerted the reader that many green wedges could have been created in the past, but little had been done in this respect. He warned that the clock was ticking and it was time to act. As envisaged by Unwin in the final report of the Greater London Regional Planning Committee (1929), Abercrombie (1945, 100) pictured a protected green canvas as the base for the plan, rather than a sea of buildings with scattered green spaces.

INSERT FIG. 7 HERE (Greater London open spaces plan) 
Twenty-four green wedges connecting the first and the third rings of the plan were proposed (see Figure 7). They were described in Appendix 20 of the plan. It is worth noting that the plan had only two appendices that referred to green spaces: 'Open Spaces Survey and Proposals' (Appdx 19) and 'Green Wedges-Proposals' (Appdx 20). Curiously enough, there was no appendix for green belts, which indicates something of the importance that Abercrombie attached to the wedges and their implementation. The wedges ranged from long to short, continuous to broken and were, as much as possible, to be converted into public recreation zones and playing fields. The wedges from the County of London Plan were all present, to which eleven more were added, including the River Thames, 'the finest natural wedge into London' (Abercrombie, 1945, 207-8). River valleys were to be used as such throughout Greater London, as they were considered to be 'very valuable as green wedges of lungs to towns in their vicinity'. In addition, they were also of 'great value in maintaining the physical separation between expanding communities, and thereby helping to maintain and emphasise their independent community life' (NA HLC $85 / 17,1944,5)$.

With regard to the plan's position in respect to agricultural land, it referred to the Scott Report and stated that farmland would not all be under green belt influence, but also referred to the 'wedges penetrating into the Suburban Ring' (Abercrombie, 1945, 103-4; see also letter from Dudley Stamp to Abercombie: NA HLG 71/116, 1944). The Scott report discussed distinct views on the idea of green belt and made a direct reference to green wedges. From the perspective of the urban dweller the green belt, the report argued, was considered to be 'a belt of open land-of commons, woods, fields - to be "preserved" from buildings and so to serve as an encircling ring of green round the smoke and dirt of the town, perhaps with "wedges" of green penetrating 
towards the heart of the town itself'. It suggested, on the other hand, that these wedges be understood 'as a tract of the countryside', and used for the production of fresh produce and for the reservation of woodland (Ministry of Works and Planning, $1942,71)$. Despite the call for seeing green wedges as tracts of rural land, the plan tended to promote the wedges mostly as parkland.

By this time, large open spaces were seen as worthy allies in times of war. Abercrombie, in his plan for Plymouth published in 1943, stated that 'parks and town gardens could withstand bombing and fire better than our solid buildings' and that war had brought forward the advantage of more spacious planning, which would lessen the effect of aerial attack and provide emergency land that could be converted into allotments to reinforce food supplies (Watson and Abercrombie, 1943, 98-9). Green wedges, as instruments of 'spacious' planning, in this respect, would help break up the mass of buildings, minimise the proliferation of fire, increase the dissipation of smoke, provide escape routes and congregation points in the event of attack, and be available for temporary conversion into allotments.

On 12 December 1944, the Minister forwarded copies of the plan to the local authorities and the County Councils for consideration. Their views were then submitted to the Advisory Committee for London Regional Planning, formed to coordinate Abercrombie's plan (LMA AR/TP/5/9, 1947, 13). A series of subcommittees was to be set up, 'Open Spaces' (LMA MCC/MIN/65/006, 1946b) being one of them. In March 1946, this sub-committee delved into the range of scales of the open spaces provision in Abercrombie's plan, ultimately supporting the whole scheme (LMA MCC/MIN/65/006, 1946a). For Silkin, the Minister of Town and Country Planning, the plan seemed feasible, however 'modest relative to need' (LMA MCC/MIN/65/006, 1946c). 
The Advisory Committee reported to Silkin, who, on 27 November 1946, circulated a memorandum back to local authorities within the area of the Greater London Plan. The Memorandum set out the Minister's views on the Report of the Advisory Committee and was sent to planning authorities to help them develop detailed schemes for their particular areas.

With regards to open spaces, the memorandum suggested that the major difference between the recommendations of the Advisory Committee and those of the Greater London Plan lay in the degree of encroachment into the green wedges and the green belt. The Minister was in agreement with the standard for open space prescribed in the Greater London Plan and expressed his intention to 'prepare a plan to show the land around London, which, as green belt or green wedges, must be preserved from development'. He also expressed his contentment over the fact that the Open Spaces Sub-Committee fully supported the proposals for green wedges within the region. For Silkin, the preservation of the green wedges was essential. They were seen as particularly vulnerable as a result of the pressure for housing and for the expansion of existing industries after the end of the conflict. As a consequence, he emphasised 'the necessity for the same strong action as will be required in safeguarding the green belt.' The minister made clear his adherence to the idea and commitment for their implementation:

'planning Authorities should not permit any development on land shown for retention as green belt or green wedges, unless they have proved to the satisfaction of the Minister that there is an unanswerable case for reconsideration of the boundaries' (LMA AR/TP/5/9, $1947,11)$.

The reception of these two plans in newspapers and professional journals tended to be minimal and mostly descriptive (Larkham and Lilley, 2001, 8, 11 and 16; see for 
instance The Estates Gazette, 1944, 550-1; The Builder, 1944, 465-9). Critical assertions about the provision of green spaces being insufficient can be found for both plans, as revealed by an article by M. Cracknell from the TCPA regarding the LCC plan, which stated that the plan was unacceptable as it stood and that the provision of green spaces should be much increased $(1943,118)$; and by E.C. Kent and F.J. Samuely's review of the Greater London Plan, which argued that 'a more radical policy would have been welcome' $(1945,324)$. On the matter of green wedges, Kent and Samuely used an image of the Lee Valley green wedge from the Greater London Plan as an example of Abercrombie's approach. The Town Planning Review, in turn, considered the articulation of traffic arteries and green spaces marking the boundaries of districts as 'the one recent great advance in the theory of the modern city' (W.A.E., 1943-7, 39).

Despite Abercrombie's and Silkin's efforts to call attention to the green wedges and to keep them building-free, the idealism behind the possibility of radically transforming London was eventually shaken by legal constraints and lack of funding. Despite the fact that the formation of the Ministry of Town and Country Planning in 1943 meant a move towards the coordination of planning also at national level, the 1943 and 1944 Town and Country Planning Acts, which gave new powers to local authorities for the acquisition of land, were perceived as unsatisfactory (Hasegawa, 1992, 5-6; Hasegawa, 1999). As Tichelar described, the 1944 Act in particular was considered by many local authorities as a 'great betrayal' and a 'triumph of the rights of property' (Cited in Essex and Brayshay, 2008, 444). With the end of the war, the economic crisis and the consequent limitation in funding for the realisation of the two plans analysed in this article, the focus was on the overwhelming need for housing and other aspects of reconstruction. 
Contrary to what could have been expected due to the slim chances of implementing green wedges in London immediately after the war, the idea would gain another boost nationally and internationally in the wake of the Greater London Plan. In this respect, it is worth noting that the use of green wedges became a recommendation of the 'Final Report of the New Towns Committee' (New Towns Committee, 1946, paragraph 60). Indeed, many plans for new towns adopted the use of green wedges in their park systems, as for instance, Harlow, Stevenage and Hemel Hempstead. Interestingly enough, the most emblematic post-war period implementation of the green wedges idea happened outside Britain, with the 1947 Finger Plan for Copenhagen (see Hall and Tewdwr-Jones, 2002, 205-6; Vejre et al., 2007, 311-28).

\section{Conclusions}

The war brought with it the feeling that the time had come to end the negative effects of unplanned growth. The responsibility of implementing radical change lay with town planning, which now had to confront the enormous challenge of replanning and reconstruction. These two plans should be viewed in the broader context of the postwar reconstruction debate. They emphasised that the benefits of radical reconstruction would greatly outweigh, in the long term, the enormous costs of demolition and building the new London.

Green wedges had four main raisons d'être. First, they had a sanitary role in bringing sunlight, fresh air and greenery to the inner parts of the city. Second, and perhaps most importantly, in a period when the countryside was increasingly distant from the city's core, these wedges allowed a direct link from the centre to the open country through pleasant green routes. Third, they were to provide easy access to 
open space, mainly recreational grounds, to every citizen. And lastly, they were instruments of planning, inasmuch as they could be used as zoning tools to connect or separate areas.

Other functions were attached to the wedges, or some that already existed were elaborated. First of all, green wedges became symbols of hope for a better and brighter future. At the same time as they opened up a physical path to the now remote countryside, they were also allegories of the search for a balanced society in harmonious contact with nature. Another specific contribution of the post-war context was the growing importance of open space in times of conflict. 'Spacious' planning was seen as a pre-emptive move against air raids and the demise of large populations. Green wedges would then help avoid the proliferation of fire in the city, as well as serve as congregation points and escape routes. In this context, they could also become temporary allotments to support food supply. With the national preoccupation with agricultural land and the need to consider town and country planning jointly in the 1940s, discourses about considering the wedges as tracts of nature or agricultural land arriving from beyond the urban fringe became stronger, and was particularly evident in the Greater London Plan. An elaboration of a previous function can be seen in the growing importance of wedges in zoning, particularly in their use as buffer zones between traffic arteries and residential areas, and as boundaries of communities.

Another important inference that can be made is that green wedges worked both at the city and regional scales, as anchors of the city in the territory. Ultimately, with the assumption of the creation of new towns around London, green wedges could assume a national dimension by interconnecting them with the capital and beyond.

There is a lack of immediate reactions to green wedges, both contemporary and in later evaluations of post-war reconstruction plans. As discussed, commentators tended 
not to focus on this aspect of park systems. It could be said that this may be due to the fact that out of all the planning debates, not much was implemented, with the exception of the green belt.

Although green wedges had been discussed by British planners for decades, few examples of their implementation could be seen. If green wedges were to go from the open country to the inner core, they needed to cut through numerous privately owned properties and administrative boundaries. These, coupled with difficulty in controlling intra-urban development, problematised their planning and most of all any attempt at their potential execution. Competing plans happening at the same time with different objectives were not uncommon, and while overall plans expected a conjoined strategy for London, boroughs and individual landowners proved to have other priorities. The immediate urge for houses also contributed to diverting the focus away from the provision of such large green spaces. Moreover, the lack of a legal apparatus and the economic crises that came with the end of the war added to the problems that needed to be overcome to implement green wedges in London.

Notwithstanding that the idea did not materialise in the capital as planned, green wedges gained a boost of popularity in the new towns. Being able to plan from scratch, with the support of the New Towns Committee, and to count on the economic and legal powers bestowed upon the new towns' corporations undoubtedly helped make green wedges a reality.

Trying to understand the post-war reconstruction debates without considering the significance that contemporary planners gave to green wedges is to see only a partial picture of the multifaceted nature of what planning for the future really meant. As we have seen here, green wedges were at the core of what London should be like today. 


\section{Acknowledgements}

The author wishes to thank the reviewers for their constructive comments, and Joshua Cherry, Tom Resch, John Paul Vout and Liam Whitfield for drawing up the diagrams.

\section{References}

ABERCROMBIE, P. (1912), 'Town Planning in Greater London: The Need for Cooperation', Town Planning Review, 2, 261-280.

ABERCROMBIE, P. (1933), Town and Country Planning, London, Oxford University Press.

ABERCROMBIE, P. and FORSHAW, J. (1943), County of London Plan prepared for the LCC, 1943, London, Macmillan.

ABERCROMBIE, P. (1945), Greater London Plan 1944, London, HMSO.

ADAMS, T. (1940), 'Town and Country Planning During the War: Memorandum by Dr Thomas Adams, The Builder, 158, 77-8.

AMATI, M. and YOKOHARI, M. (1997), 'The Establishment of the London Greenbelt', Planning Perspectives, 6, 311-37.

ASHWORTH, W. (1954), The Genesis of Modern British Town Planning, London, Routledge \& Kegan Paul.

BULLOCK, N. (1994), 'Ideals, priorities and harsh realities: Reconstruction and the LCC, 1945-51', Planning Perspectives, 9, 87-101.

BULLOCK, N. (2002), Building the Post-War World Modern architecture and reconstruction in Britain, London, Routledge.

CARTER, E. J. and GOLDFINGER, E. (eds) (1945), The County of London Plan explained by E. J. Carter and Erno Goldfinger, London, Penguin Books.

CHERRY, G. (1975), Environmental Planning 1939-1969, Volume II - National Parks and Recreation in the Countryside, London.

CHERRY, G. (1988), The Evolution of British Town Planning: A History of Town Planning in the United Kingdom, Leighton Buzzard, L. Hill.

CRACKNELL, M. (1943), 'County of London Plan ... a statement by the executive of the Town \& Country Planning Association', Town and Country Planning, 11, 118-27.

CRAMPTON, A. W. (1941), 'Town Planning and Reconstruction, to The Editor of The Builder', The Builder, 160, 4-5.

CULLINGWORTH, J. B. (1975), Reconstruction and land use planning 1939-1947, London, HMSO.

DAL CO, F. (1980), 'From Parks to the Region', in G. Ciucci (ed), The American City: From the Civil War to the New Deal, London, Granada, 141-293.

DÜMPELMANN, S. (2005), 'The Park International: Park System Planning as an International Phenomenon at the Beginning of the Twentieth Century', GHI Bulletin, Fall, 75-86. 
EBERSTADT, R. (1911), 'Town Planning in Germany: The Greater Berlin Competition', in Royal Institute of British Architects (RIBA) (ed), Town Planning Conference, London, 10-15 October 1910. Transactions, London, RIBA, 313-32.

ESSEX, S. and BRAYSHAY, M. (2008), 'Boldness diminished? The post-war battle to replan a bomb-damaged provincial city', Urban History, 35, 437-61.

FLINN, C. (2012), “"The City of our Dreams”? The Political and Economic Realities of Rebuilding Britain's Blitzed Cities, 1945-54', Twentieth Century British History, 23, 221-45.

FORSHAW, J. H. (1943), 'Town Planning and Health. Mr Forshaw's Chadwick Trust Lecture', The Builder, Nov-Dec, 14-15.

FREESTONE, R. (2003), 'Greenbelts in City and Regional Planning', in K. Parsons (ed), From Garden City to Green City: The Legacy of Ebenezer Howard, Baltimore, John Hopkins University Press, 67-98.

GIBSON, D. E. (1940), 'Problems of Building Reconstruction', The Builder, 159, 579.

GOLD, J. (1995), 'The MARS plans for London, 1933-1942', Town Planning Review, 66, 243-67.

GREATER LONDON REGIONAL PLANNING COMMITTEE (GLRPC) (1929), First Report of the Greater London Regional Planning Committee, London, Knapp, Drewett \& Sons.

GREATER LONDON REGIONAL PLANNING COMMITTEE (GLRP) (1933), Second Report of the Greater London Regional Planning Committee, London, Knapp, Drewett \& Sons.

HALL, P. and TEWDWR-JONES, M. (2011), Urban and Regional Planning, Abingdon, Routledge.

HASEGAWA, J. (1992), Replanning the blitzed city centre: a comparative study of Bristol, Coventry and Southampton 1941-1950, Buckingham, Open University Press.

HASEGAWA, J. (1999), 'The Rise and Fall of Reconstruction in 1940s Britain', Twentieth Century British History, 10, 137-61.

HEWITT, L. (2011), 'Towards a Greater Urban Geography: Regional Planning and Associational Networks in London during the Early Twentieth Century', Planning Perspectives, 26, 551-68.

JONES, P. N. (1998), ““... fa fairer and nobler city”-Lutyens and Abercrombie's plan for the City of Hull 1945', Planning Perspectives, 13, 301-16.

KENT, E.C. and SAMUELY, F.J (1945), 'London: The Regional Plan-An Analysis of Sir Patrick Abercrombie's Scheme, The Architects' Journal, Nov, 313-26.

LANCHESTER, H. V. (1941), 'An Architect's View of Reconstruction: The Large City', The Builder, 161, 569.

LANCHESTER, H. V . (1943), 'Replanning London', The Builder, 165, 41.

LARKHAM, P. J. and ADAMS, D. (2011), 'The post-war reconstruction planning of London: a wider perspective' (Working Paper Series No. 8), Birmingham, Birmingham City University.

LARKHAM, P. J. and LILLEY, K. D. (2001), Planning the 'City of Tomorrow'. British reconstruction planning, 1939-1952: an annotated bibliography, Pickering, Inch's books.

LATHAM, C. (1942), 'The planning problems of London: Lord Latham's survey', The Builder, 162, 421-3.

LEMES DE OLIVEIRA, F. (2013), 'Green Wedges', London Society Journal 465, 11-13. 
LEMES DE OLIVEIRA, F. (2014), 'Green wedges: origins and development in Britain', Planning Perspectives, 29:3, 357-79.

LMA (LONDON METROPOLITAN ARCHIVES) AR/TP/5/9 (1947), 'Greater London Plan, Memorandum by the Ministry of Town and Country Planning on the Report of the Advisory Committee for London Regional Planning', London, London Metropolitan Archives.

LMA (LONDON METROPOLITAN ARCHIVES) CL/TP/1/33 (1940a), 'London County Council. Memorandum on Replanning and Reconstruction of London, first draft', London, London Metropolitan Archives.

LMA (LONDON METROPOLITAN ARCHIVES) CL/TP/1/33 (1940b), 'London County Council. Post-War Reconstruction of London, Notes of a conference held on $7^{\text {th }}$ October, 1940', London, London Metropolitan Archives.

LMA (LONDON METROPOLITAN ARCHIVES) CL/TP/1/33 (1940c), 'London County Council. Memorandum by the Architect, $6^{\text {th }}$ December 1940', London, London Metropolitan Archives.

LMA (LONDON METROPOLITAN ARCHIVES) CL/TP/1/33 (1940d), 'London County Council. Interview with Comptroller and Mr Miles, December 1940', London, London Metropolitan Archives.

LMA (LONDON METROPOLITAN ARCHIVES) CL/TP/1/33 (1941a), 'London County Council. Memorandum from the Architect to the Council, $18^{\text {th }}$ February 1941', London, London Metropolitan Archives.

LMA (LONDON METROPOLITAN ARCHIVES) CL/TP/1/33 (1941b), 'London County Council. Letter from the Clerk of the Council to Professor Abercrombie, $8^{\text {th }}$ April 1941', London, London Metropolitan Archives.

LMA (LONDON METROPOLITAN ARCHIVES) CL/TP/1/34 (1941), 'London County Council. Letter, $8^{\text {th }}$ April 1941', London, London Metropolitan Archives.

LMA (LONDON METROPOLITAN ARCHIVES) CL/TP/1/34 (1943a), 'London County Council. Letter from the Clerk of the Council, $13^{\text {th }}$ July 1943', London, London Metropolitan Archives.

LMA (LONDON METROPOLITAN ARCHIVES) CL/TP/1/34 (1943b), 'London County Council. County of London Plan. Report $(04.06 .43)$ by Chief Officer of the Parks Department'.

LMA (LONDON METROPOLITAN ARCHIVES) CL/TP/1/34 (1943c), 'London County Council. County of London Plan. Parks Committee. Report (31.05.43) by Comptroller of the Council', London, London Metropolitan Archives.

LMA (LONDON METROPOLITAN ARCHIVES) CL/TP/1/34 (1943d), 'London County Council. County of London Plan. Parks Committee. Report (31.05.43) by Comptroller of the Council', London, London Metropolitan Archives.

LMA (LONDON METROPOLITAN ARCHIVES) CL/TP/1/34 (1944), 'London County Council. County of London Plan-Housing Density. Housing and Public Health Committee. Joint Report by Architect, Chief Assistant, Valuer and Comptroller of the Council. 17 ${ }^{\text {th }}$ July 1944', London, London Metropolitan Archives.

LMA (LONDON METROPOLITAN ARCHIVES) CL/TP/1/34 (1945), 'London County Council. County of London Plan. Observations by Government Departments, Metropolitan Borough Councils and Other Bodies-Open Space Proposals. Town Planning Committee. Report (4.1.45) by Comptroller of the Council. A. R. Wood', London, London Metropolitan Archives. 
LMA (LONDON METROPOLITAN ARCHIVES) CL/TP/1/37 (1943), 'London County Council. Town Planning Committee. Report by Valuer (24.05.43)', London, London Metropolitan Archives.

LMA (LONDON METROPOLITAN ARCHIVES) CL/TP/37 (1944), 'London County Council. County of London Plan. Observations by Government Departments, Metropolitan Borough Councils and Other Bodies-Open Space Proposals. Town Planning Committee. Report (12.10.44) by Architect (No.4)', London, London Metropolitan Archives.

LMA (LONDON METROPOLITAN ARCHIVES) CL/TP/37 (1945), 'London County Council. County of London Plan. Town Planning Committee. Draft Report of the Town Planning Committee. $11^{\text {th }}$ June 1945. Eric Salmon, Clerk of the Council', London, London Metropolitan Archives.

LMA (LONDON METROPOLITAN ARCHIVES) LMA/4062/06/040 (1943), "'London County Council, 'Exhibition of the County of London Plan', 1943', London, London Metropolitan Archives.

LMA (LONDON METROPOLITAN ARCHIVES) MCC/MIN/65/006 (1946a), 'Advisory Committee for London Regional Planning. Open Spaces sub-committee. $20^{\text {th }}$ March 1946', London, London Metropolitan Archives.

LMA (LONDON METROPOLITAN ARCHIVES) MCC/MIN/65/006 (1946b), 'Draft Memorandum on General Principles to be Adopted by Technical SubCommittee. Harry Stewart, Chief Technical Officer, $25^{\text {th }}$ February 1946', London, London Metropolitan Archives.

LMA (LONDON METROPOLITAN ARCHIVES) MCC/MIN/65/006 (1946c). 'Greater London Plan-Open spaces and Recreation Areas. Memorandum prepared for Interdepartmental Committee by the Ministry of Town and Country Planning. $8^{\text {th }}$ April 1946', London, London Metropolitan Archives.

MARMARAS, E. and SUTCLIFFE, A. (1994), 'Planning for post-war London: The three independent plans, 1942-3', Planning Perspectives, 9, 431-53.

MINISTRY OF WORKS AND PLANNING (1942), Report of the Committee on Land Utilization in Rural Areas (Scott Report), Cmd 6378, London, HMSO.

MOORE, V. (2012), A Practical Approach to Planning Law, Oxford, Oxford University Press.

NA (NATIONAL ARCHIVES) HLC 85/17 (1944), 'Greater London Plan. Individual matters for comment, etc. Open Spaces, 14 January 1944', London, National Archives.

NA (NATIONAL ARCHIVES) HLG 71/116 (1941a), 'L.C.C. Outline Plan', 17 September 1941, London, National Archives.

NA (NATIONAL ARCHIVES) HLG 71/116 (1941b), 'Letter. Minister. 27 September 1941', London, National Archives.

NA (NATIONAL ARCHIVES) HLG 71/116 (1941c), 'Notes on a meeting between Mr Salmon, Professor Abercrombie Mr Forshaw, Mr Pepler and H.Y.L. 16 September 1941', London, National Archives.

NA (NATIONAL ARCHIVES) HLG 71/116 (1944), 'Letter from L. Dudley Stamp to P. Abercrombie, 8 January 1944', London, National Archives.

NA (NATIONAL ARCHIVES) HLG 79/375 (1943-4), 'County of London Plan 1943: Consultation with the Ministry of Works', London, National Archives.

NA (NATIONAL ARCHIVES) HLG 79/376 (1943-6), "County of London Plan 1943: Consultation with the Ministry of Works', London, National Archives.

NA (NATIONAL ARCHIVES) HLG 86/7 (1941-2), 'Consultative Panel on Physical Reconstruction', London, National Archives. 
NEW TOWNS COMMITTEE (1946), Final Report of the New Towns Committee (Cmd 6876).

OSBORN, F. and WHITTICK, A. (1969), The New Towns: the answer to megalopolis, London, Leonard Hill.

PEPLER, G. (1923), 'Open Spaces', Town Planning Review, 10, 11-24.

PURDOM, C.B. (1945), How Should we Rebuild London?, London, J.M. Dent \& Sons.

REISS, R. L. (1943), 'The London Plan and Satellite Town. Address to Town and Country Planning Association', The Builder, Sept, 254.

SHEAIL, J. (1981), Rural Conservation in Inter-War Britain, Oxford, Oxford University Press.

SILKIN, L. (1943), 'London Replanned: Decentralization of Industry and Population', The Times, 13 July, 5.

SUTCLIFFE, A. (1981). British Town Planning: the Formative Years, Leicester, Leicester University Press.

Sutcliffe, A. (1981b). Towards the Planned City: Germany, Britain, the United States and France, 1780-1914, Oxford, Basil Blackwell.

THE BUILDER (1942a), 'In Parliament: Replanning of London', The Builder, 162, 563.

THE BUILDER (1942b), 'Town and Country Planning', The Builder, 162, 333.

THE BUILDER (1944), 'The Greater London Plan', The Builder, 167, 465-9.

THE ESTATES GAZETTE (1944), 'The Greater London: Professor Abercrombie outline', The Estates Gazette, December 16, 550-51.

TICHELAR, M. (2003), 'The conflict over property rights during the Second World War: the Labour Party's abandonment of land nationalization', Twentieth Century British History, 14, 165-88.

TIRATSOO, N. (2000), 'The reconstruction of blitzed British cities 1945-55: Myths and reality', Contemporary British History, 14, 27-44.

TRYSTAN EDWARDS, A. (1941). "A Plan for 'Greater London”", The Builder, February 5, 128-9.

TUBBS, R. (1942). Living in Cities, London, Penguin.

W.A.E. (1943-7), 'Book reviews: the County of London Plan', Town Planning Review, 19, 38-41.

WARD, S. (2002), Planning the Twentieth-Century City: The Advanced Capitalist World, Chichester, Wiley.

WARD, S. (2004), Planning and Urban Change, London, Sage.

WATSON, J. P. and ABERCROMBIE, P. (1943), A Plan for Plymouth: The Report Prepared for the City Council, Plymouth, Underhill.

Total word count: 9,441 